\title{
Clonal Analysis of Human Tumors with M27 $\beta$, a Highly Informative Polymorphic X Chromosomal Probe
}

\author{
Martin F. Fey, ${ }^{\star *}$ Hans-Jakob Peter," Heather L. Hinds," Arthur Zimmermann," Sabina Liechti-Gallati, "* Hans Gerber," \\ Hugo Studer, and Andreas Tobler, \\ ${ }^{*}$ Institute of Medical Oncology, Inselspital, Berne, Switzerland; ${ }^{\ddagger}$ Laboratory for Clinical and Experimental Research, Tiefenauspital, \\ Berne, Switzerland; 'Department of Medicine, Inselspital, Berne, Switzerland; "Genetics Laboratory, Department of Biochemistry, \\ University of Oxford, United Kingdom; 'Department of Pathology, University of Berne, Berne, Switzerland; **Division of Genetics, \\ Department of Paediatrics, Inselspital Berne, Switzerland; and ${ }^{\ddagger}$ Central Haematology Laboratory, Inselspital Berne, Switzerland
}

\section{Abstract}

The clonality of human tumors can be studied by $\mathbf{X}$ inactivation/methylation analysis in female patients heterozygous for X-linked DNA polymorphisms. We present a detailed study on clonal tumor analysis with $\mathrm{M} 27 \beta$, a highly informative probe detecting a polymorphic X chromosomal locus, DXS255. The polymorphism detected at this locus is due to variable numbers of tandem repeats. The rate of constitutional heterozygosity detected by M27 $\beta$ was $\mathbf{8 8 \%}$. Normal tissue from gastrointestinal mucosa and thyroid showed random, hence polyclonal, patterns. Nonrandom clonal $X$ inactivation was detected in all 22 malignant neoplasms that had been shown to be clonal by other DNA markers, such as antigen receptor gene rearrangements or clonal loss of heterozygosity at 17p and other loci. 16/48 normal blood leukocyte samples (33\%) showed considerably skewed $\mathbf{X}$ inactivation patterns. Comparison of blood leukocytes and normal tissue indicated that in a given individual, $X$ inactivation patterns may be tissue specific. M27 $\beta$ was used to study the clonal composition of 13 benign thyroid nodules from 12 multinodular goiters with rapid recent growth, traditionally termed "adenomas." Nine of them were clonal, whereas four nodules and tissue from a case of Graves' goiter were not, indicating that some, but not all, such thyroid nodules may represent true clonal neoplasms. The M27 $\beta$ probe permits one to study the clonal composition by the $X$ inactivation approach of a wide variety of solid tumors from most female patients. As a control, normal tissue homologous to the tumor type of interest is preferable to DNA from blood leukocytes, since the latter may show nonrandom $X$ inactivation patterns in a fairly high proportion of cases. M27 $\beta$ may, therefore, be of limited use for the clonal analysis of neoplasms derived from hematopoietic cells. (J. Clin. Invest. 1992. 89:1438-1444.) Key words: X chromosome methylation • X-linked VNTR • tumor clonality • thyroid nodules $\bullet \mathbf{X}$ inactivation skewing

Part of this work was presented as an Abstract at the 59th Annual Meeting of the Swiss Society of Haematology in Lugano (Switzerland), 1991.

Address correspondence and reprint requests to Dr. Martin F. Fey, Institute of Medical Oncology, Inselspital, University of Berne, $\mathrm{CH}$ 3010 Berne, Switzerland.

Received for publication 27 August 1991 and in revised form 30 December 1991.

J. Clin. Invest.

(C) The American Society for Clinical Investigation, Inc.

$0021-9738 / 92 / 05 / 1438 / 07 \quad \$ 2.00$

Volume 89, May 1992, 1438-1444
Introduction

The somatic mutation theory of carcinogenesis predicts that a malignant neoplasm is clonal, representing the progeny of a single mutated somatic cell having acquired a selective growth advantage over its normal counterparts $(1,2)$. Molecular analysis of tumor clonality is extremely helpful in elucidating the molecular underpinnings of tumor development, and it may be practically useful, for example, to sort out reactive from neoplastic cell populations in lymphoproliferative disorders by the detection of antigen receptor gene rearrangements $(3,4)$. In many settings, both experimental and diagnostic, a generally applicable strategy of assessing tumor clonality independent from the tumor type of interest would be welcome, particularly when no tumor-specific DNA markers are available. One such approach is the clonal analysis by DNA "fingerprinting" to detect somatic mutations at minisatellite loci in tumor DNA (5). Another principle of assessing the clonality in a wide variety of different tumors was originally proposed by Fialkow et al. $(2,6,7)$, and more recently extended by Vogelstein et al. $(8$, 9). It makes use of differential $X$ inactivation patterns in female individuals heterozygous for $\mathrm{X}$-linked polymorphisms. According to Lyon's hypothesis, only one of two alleles at a given $\mathrm{X}$ chromosomal locus will be expressed in a particular somatic cell. In a female heterozygous for an X-linked polymorphism, tissues with a polyclonal composition will display $X$ inactivation of the normal and the polymorphic allele at a 1:1 ratio. In contrast, in a neoplasm derived from a single somatic cell, all the tumor cells would retain the same $\mathrm{X}$ inactivation pattern.

Clonal tumor analysis by this principle originally made use of a protein polymorphism, the glucose-6-phosphate-dehydrogenase isoenzymes (G6PD) found mainly in Blacks (2). The study of $\mathrm{X}$ inactivation at the DNA level has greatly expanded the scope of this strategy. This type of assessing tumor clonality is based on comparing $X$ inactivation patterns in normal and tumor DNA with the help of methylation-sensitive restriction enzymes $(9,10)$. In the past few years, this approach has been widely used to study the clonal composition of many different neoplasms (10-13). The most widely used $X$ polymorphisms are restriction fragment length polymorphisms (RFLP) ${ }^{1}$ in the hypoxanthine phosphoribosyl transferase (HPRT) and the phosphoglycerate kinase (PGK) genes (9). Since these RFLPs

1. Abbreviations used in this paper: $\mathrm{ACR}$, allelic cleavage ratio; HPRT, hypoxanthine phosphoribosyl transferase; JH, immunoglobulin heavy-chain joining region gene probe; PGK, phosphoglycerate kinase; RFLP, restriction fragment length polymorphisms; VNTR, variable numbers of tandem repeats. 
are bimorphisms, constitutional heterozygosity may at best be $50 \%$, but it is frequently lower. Therefore, many patients are constitutionally homozygous, and hence, uninformative, for assessment of tumor clonality by $\mathrm{X}$ inactivation analysis.

Recent reports on assessing tumor clonality with a novel highly polymorphic $\mathrm{X}$ chromosomal probe, $\mathrm{M} 27 \beta$, have elicited the hope that this probe might overcome the limitations of X-RFLP analysis using bimorphic PGK and HPRT polymorphisms $(14,15)$. The polymorphism detected by $M 27 \beta$ is due to the presence at this locus (DXS255) of variable numbers of tandem repeats (VNTR) responsible for allelic hypervariability $(16,17)$. Restriction fragments containing the VNTR sequence harbour methylation-sensitive HpaII sites at their 5' end (1820) suitable to identify active and inactive alleles. The high rate of heterozygosity of about $90 \%$ detected by M27 $\beta$ (16) might permit assessment of clonality of tissue specimens by $\mathrm{X}$ inactivation analysis in virtually all female patients. In particular, the use of this single highly informative probe would obviate the need for screening patients with many different restriction enzymes and $\mathrm{X}$ chromosomal probes, in order to find informative markers (9). We now present a detailed analysis of the use of M27 $\beta$ in assessing tumor clonality, including its application to the study of benign thyroid nodules of uncertain clonal composition.

\section{Methods}

\section{Patients and controls}

We analyzed 86 unrelated Caucasian females to determine the rate of constitutional heterozygosity detected by M27 $\beta$, and the methylation patterns of normal whole blood leukocyte DNA in 48 of them. 22 cases of malignant neoplasms were used to assess the use of the M27 $\beta$ probe for clonal analysis. This series included 11 colorectal and four gastric cancers, two thyroid carcinomas, three leukemias and two malignant lymphomas (Table I). In addition, M27 $\beta$ was used to assess the clonality of 13 thyroid nodules from 12 patients with multinodular goiters and of one case of Graves' goiter (Table II). All of these had shown rapid recent growth necessitating surgical removal, and were histologically benign.

\section{Tissue and DNA preparation}

The diagnoses of the malignant neoplasias and the thyroid lesions were made by routine microscopical examination of cytological and histological specimens. Sources of constitutional DNA were whole blood leukocytes, and specimens of histologically normal tissue from gastrointestinal mucosa (stripped from the underlying lamina muscularis propria) or thyroid, respectively. Tumor and normal tissue samples were collected freshly at surgery. Macroscopically, nonneoplastic or necrotic tissue was removed with a scalpel. Tumor samples selected for clonal analysis contained at least $60 \%$ tumor cells, as assessed by histological examination of representative slides taken from either end and at regular intervals from the central areas of each tissue block used for DNA extraction. Tissue from thyroid nodules was taken so as to avoid contamination with normal surrounding tissue. In the leukemias, mononuclear cells were prepared by Ficoll density gradient $(d=1.077 \mathrm{~g} /$ liter $)$ centrifugation from bone marrow obtained at diagnosis, and samples taken for M27 $\beta$ analysis contained $\geq 80 \%$ of malignant cells as assessed in cytospin preparations. DNA was extracted by standard techniques. An undigested aliquot from each sample was electrophoresed on an agarose gel to identify samples with DNA degradation.

\section{Clonal analysis of tumors}

M27 $\beta$ analysis. Rationale of clonal analysis with M27 $\beta$ : $(A)$ the alleles present at the highly polymorphic X chromosomal locus DXS255 can be detected by hybridizing Southern blots of PstI digested DNA with the $\mathrm{M} 27 \beta$ probe (Fig. 1). Variability of the alleles is due to the presence of differing numbers of a 26-base pair tandem repeat located within the Pstl fragments recognized by the probe $(16,17)$. (B) Active and inactive alleles can be distinguished by the examination of methylation patterns at cytosine residues. The methylation-sensitive enzyme HpalI cuts its recognition sequence $(\mathrm{C} / \mathrm{CGG})$ only when the internal $\mathrm{C}$ residue is not methylated, whilst MspI (an Hpall isoschizomer) cleaves irrespective of methylation at this site. The M27 $\beta$ PstI fragments contain towards their $5^{\prime}$ end a region with three methylation-sensitive sites (M1-M3 in Fig. 1 ; H. L. Hinds, manuscript in preparation). M2 corresponds to the single HpaII site reported previously $(14,19)$ which has been characterized as being methylated on the active $X$, and unmethylated on the inactive $X(18-20)$. Unpublished observations suggest that all three Hpall sites (M1-3) are always methylated on the active X chromosome. On the inactive $\mathrm{X}$ chromosome $\mathrm{M} 1$ and $\mathrm{M} 2$ are partially or completely unmethylated, while $\mathrm{M} 3$ is consistently methylated (21, 22; H. L. Hinds, manuscript in preparation). Inspection of the map predicts that since Hpall cannot cut at M3, HpalI cleavage of a PstI fragment at M2 will shift the PstI/HpaII band to a position just at or slightly above the PstI/MspI fragment. This pattern is frequently seen in our normal tissue samples, and always present on the inactive $\mathrm{X}$ in our series of clonal tumors. Partial methylation at M2 on the inactive $\mathrm{X}$ may result in some alleles being cleaved at $\mathrm{M} 1$, if this site is unmethylated, or the PstI fragment may not be cut at all on those inactive $\mathrm{X}$ chromosomes where both $\mathrm{M} 1$ and $\mathrm{M} 2$ are methylated. $(C)$ Random and nonrandom $\mathrm{X}$ inactivation patterns: in polyclonal female tissues equal proportions of cells with either the paternal or the maternal $\mathrm{X}$ inactivated should be present, and HpalI cleavage of inactive PstI alleles to smaller PstI/HpaII alleles should occur to equal extents for both parental alleles. Preferential HpaII cleavage of one PstI allele over the other reflects biased patterns of $X$ inactivation resulting from nonequal mixtures of cell types with paternal and maternal $\mathrm{X}$ inactivation. Clonal tumors derived from a single progenitor cell represent the extreme case of nonrandom X chromosomal use, since the $\mathrm{X}$ methylation pattern present in the cell of origin will be retained in its progeny. Therefore, in DNA from a clonal tumor, Hpall cleavage of inactive PstI alleles to smaller PstI/HpaII alleles will occur only for one parental allele.

Technique of clonal M27 $\beta$ analysis. $30 \mu \mathrm{g}$ of DNA were digested with PstI $(10 \mathrm{U} / \mu \mathrm{g})$, precipitated, redissolved in $\mathrm{H}_{2} \mathrm{O}$, and split into $10-\mu \mathrm{g}$ aliquots $(\mathrm{A}-\mathrm{C})$. Aliquots $\mathrm{B}$ and $\mathrm{C}$ were digested further; $\mathrm{B}$ with HpalI $(30 \mathrm{U} / \mu \mathrm{g})$, and $\mathrm{C}$ with $\mathrm{MspI}(10 \mathrm{U} / \mu \mathrm{g})$. In each case, aliquots A-C prepared from normal and tumor samples were electrophoresed in $1 \%(\mathrm{wt} / \mathrm{vol})$ agarose gels at $2.3 \mathrm{~V} / \mathrm{cm}$ for various periods of time suitable to obtain optimal resolution of the alleles in particular cases. Southern blots were hybridized to ${ }^{32} \mathrm{P}$-random primer labeled M27 $\beta$ probe, washed under stringent conditions (final wash in $0.1 \times$ standard saline citrate $/ 0.1 \%$ sodium dodecyl sulphate at $55^{\circ} \mathrm{C}$ to $65^{\circ} \mathrm{C}$ ), and subjected to autoradiography at $-70^{\circ} \mathrm{C}$, with intensifying screens for 4 $\mathrm{d}$ to $3 \mathrm{wk}$. To check for the quality of Hpall digests, all filters used for M27 $\beta$ analysis were rehybridized with an immunoglobulin heavy-

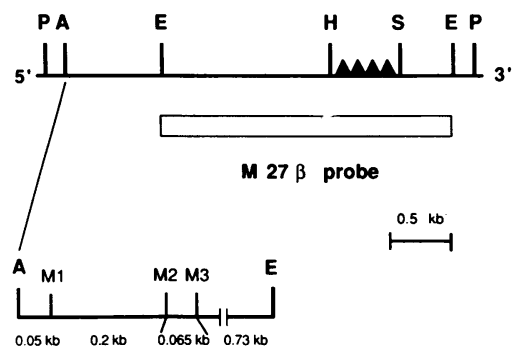

Figure 1. Partial restriction map of the locus DXS255 detected by the probe M27 $\beta$. VNTR region marked by hatched triangles. M27 $\beta$ probe indicated by dotted bar. Enzymes: $A$ : AvaII; $E$ : EcoRI; $H$ : HaeIII; $P$ : PstI; $S$ : Sau3A. (Insert below left) enlarged sketch of the AvalI-EcoRI fragment at the $5^{\prime}$ end of the M27 $\beta$-PstI fragment containing the methylation-sensitive HpaII/ MspI sites (M1, M2, and M3). 
A

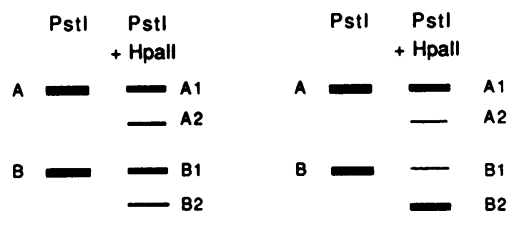

Figure 2. Determination of allelic cleavage ratio by densitometry of autoradiographs. Schematic representation of Southern blots hybridized with the $\mathrm{M} 27 \beta$ probe. $(A)$ and $(B)$ PstI fragments identified by $\mathrm{M} 27 \beta ;(A 1)$ and $(B 1)$ fragments resistant to Hpall digestion representing methylated active alleles and the methylated fraction of inactive alleles; (A2) and (B2) fragments cut by both PstI and HpaII exclusively representing inactive alleles. The ACR is calculated according to the following formula: $A C R=A / A_{2}$ divided by $B / B_{2}$. Panel $A$ : random $\mathrm{X}$ inactivation; Panel $B$ : nonrandom $\mathrm{X}$ inactivation seen in clonal tumor samples.

chain joining region gene probe $(\mathrm{JH})(23)$ : this probe detects a $4.5-\mathrm{kb}$ PstI fragment which is cut into smaller fragments by Hpall.

HPRT and PGK analysis. Clonal $\mathrm{X}$ inactivation analysis with probes detecting HPRT and PGK RFLPs was done in informative cases, as described (9).

Assessment of allelic cleavage ratio ( $A C R$ ). All M27 $\beta$ autoradiographs were scanned with a laser densitometer (2202 Ultrascan; LKB Bromma, Sweden). ACR were calculated from densitometric values of band intensities, as shown in Fig. $2(10,24)$. It is more accurate to calculate ACRs from Pstl/Hpall bands representing unmethylated inactive alleles. In those individuals with partial methylation of inactive alleles, the PstI fragments resistent to HpaII cleavage are not truly representative of the active $X$, since they also include methylated inactive alleles $(21,22)$. ACR of $<1.0$ are reported as reciprocal values.
Assessment of tumor clonality by strategies other than $X$ inactivation analysis (Table I). Gastrointestinal and thyroid carcinomas were investigated for clonal loss of heterozygosity with locus-specific VNTR probes (EcoRI, Hinfl, MspI and SstI digests; 25). Four cancers which were either uninformative or did not show any clonal allelic losses detected with our battery of VNTR probes were studied by DNA fingerprinting (5). Leukemias and lymphomas were studied by immunogenotyping with antigen receptor gene probes (BgIII, EcoRI, and HindIII digests), as described (26).

\section{DNA probes}

$\mathrm{M} 27 \beta$ is a 2.3-kb EcoRI fragment in pUC9 from an anonymous single copy genomic clone at Xp11.22 (DXS255) $(16,17)$. The HPRT probe is a 0.8-kb BamHI/PstI fragment from pHPRT-800, and the PGK probe is a 0.8-kb BamHI/EcoRI fragment from pSPT/PGK (9). The following probes detecting DNA polymorphisms (locus-specific VNTR probes) were used to detect clonal allele loss in tumors: $\lambda$ MS1 (1p3.3-3.5), $\lambda$ MS32 (1q4.2-4.3), $\lambda$ MS8 (5q3.5 ter) (27), pYNZ22 (17p) (28), pMUC10 (1q2.1-2.4) (29), and OL VII E10 (18q21.3) (30). DNA fingerprints were detected by the probes 33.6 and 33.15 (31). C76R51A (2.5-kb EcoRI fragment), a JH probe (23), and M131B10BB1 (0.7-kb EcoRI/HindIII fragment), a human cDNA probe for the $T$ cell receptor $\beta$-chain constant region gene (TCR C $\beta$ ) (32) were used for immunogenotyping.

\section{Results}

Analysis of constitutional DNA at DXS255 and other X chromosomal loci. 76 of 86 unrelated Caucasian female individuals (88\%) were constitutionally heterozygous at the locus DXS255.

Table I. Clonal Analysis of Human Malignant Neoplasms with the M27ß Probe and Independent Clonal DNA Markers

\begin{tabular}{|c|c|c|c|c|c|}
\hline \multirow[b]{2}{*}{ Case } & \multirow[b]{2}{*}{ Diagnosis } & \multicolumn{3}{|c|}{ M27 $\beta$ probe:allelic cleavage ratio } & \multirow{2}{*}{$\frac{\text { Separate clonality test }}{\text { Tumor }^{*}}$} \\
\hline & & WBC & $\begin{array}{l}\text { Normal } \\
\text { tissue* }\end{array}$ & Tumor & \\
\hline 1 & Rectal carcinoma & 1.2 & 1.1 & 50 & Loss of heterozygosity at $17 p$ \\
\hline 2 & Colon carcinoma & 8.0 & 1.2 & 40 & Mutation in DNA 'fingerprint' (5) \\
\hline 3 & Colon carcinoma & 2.0 & 1.2 & 3.0 & Loss of heterozygosity at $5 q$ and $17 p(25)$ \\
\hline 4 & Colon carcinoma & NA & 1.0 & 5.0 & Loss of heterozygosity at $17 \mathrm{p}(25)$ \\
\hline 5 & Rectal carcinoma & 2.7 & 1.0 & 2.7 & Loss of heterozygosity at $\mathrm{lq}(25)$ \\
\hline 6 & Rectal carcinoma & 1.0 & 1.3 & 90 & Loss of heterozygosity at $17 p(25)$ \\
\hline 7 & Colon carcinoma & 1.0 & 1.0 & 100 & Loss of heterozygosity at $17 \mathrm{p}(25)$ \\
\hline 8 & Colon carcioma & 1.5 & 1.1 & 86 & Loss of heterozygosity at $17 p(25)$ \\
\hline 9 & Gastric carcinoma & 1.1 & 1.7 & 24 & Loss of heterozygosity at $1 \mathrm{p}(25)$ \\
\hline 10 & Gastric carcinoma & 1.7 & 1.6 & 4.4 & Rearranged novel band at VNTR locus on $1 \mathrm{q}$ \\
\hline 11 & Colon carcinoma & 8.0 & 1.2 & 94 & Loss of heterozygosity at $1 \mathrm{q}$ and $18 \mathrm{q}$ \\
\hline 12 & Colon carcinoma & 1.0 & 1.6 & 53 & Loss of heterozygosity at $18 \mathrm{q}$ \\
\hline 13 & Gastric carcinoma & 2.5 & 1.1 & 72 & Mutation of DNA fingerprint \\
\hline 14 & Gastric carcinoma & $10^{5}$ & 1.0 & 10 & Loss of heterozygosity at $1 \mathrm{q}$ \\
\hline 15 & Colon carcinoma & 3.6 & 1.0 & 10 & Mutation in DNA fingerprint \\
\hline 16 & Thyroid carcinoma & NA & 1.1 & 85 & Loss of heterozygosity at $1 p$ and DNA fingerprint mutation \\
\hline 17 & Thyroid carcinoma & NA & 1.0 & 5.0 & Loss of heterozygosity at $17 p$ \\
\hline 18 & Pre-B-ALL & NA & NA & 12.5 & Ig heavy-chain gene rearrangement \\
\hline 19 & Pre-B-ALL & NA & NA & 50 & Ig heavy chain gene rearrangement \\
\hline 20 & Pre-B-ALL & NA & NA & 100 & Ig heavy-chain gene rearrangement \\
\hline 21 & B cell NHL & 1.2 & NA & 2.7 & Ig heavy-chain gene rearrangement \\
\hline 22 & T cell NHL & 2.0 & NA & 20 & TCR C $\beta$ gene rearrangement \\
\hline
\end{tabular}

* Sources of normal tissue: colorectal mucosa, gastric mucosa, and thyroid tissue for colorectal, gastric, and thyroid cancers, respectively. ${ }^{\ddagger}$ Data taken from previous publications, as referenced. ${ }^{8}$ Histologically normal splenic tissue, with germline Ig heavy-chain and TCR C $\beta$ genes. Ig, immunogloublin gene; NA, not available; WBC, white blood cells. 
Pstl fragments detected by M27 $\beta$ were in the range of 4.6$19.5 \mathrm{~kb}$.

In 17 of 22 cancer patients informative for M27 $\beta$ analysis, constitutional DNA from normal tissue (gastrointestinal mucosa or thyroid) homologous to the tumor type studied was available (Table I). In all of these samples, HpaII reduced the intensity of both PstI alleles more or less equally with ACRs in the range of 1.0-1.7, indicating random $\mathrm{X}$ inactivation. DNA samples with ACR values within this range were, therefore, considered to represent polyclonal tissues (consistent with references 9 and 10). In 13 of these 17 cancer patients, comparative M27 $\beta$ analysis of DNA from both peripheral blood leukocytes and normal tissue was possible; in six of them (cases 2, 3, 5, 11, 13 , and 15) with random $X$ inactivation patterns in normal mucosa, ACR values of whole blood leukocyte DNA were considerably skewed $(8.0 ; 2.0 ; 2.7 ; 8.0 ; 2.5 ;$ and 3.6 , respectively), suggestive of nonrandom $X$ inactivation (Fig. 3). Interestingly, in case 14, DNA from normal splenic tissue displayed remarkable skewing of $X$ inactivation with an ACR of 10 . This sample was histologically normal, and immunogenotyping failed to detect any clonally rearranged lg heavy-chain or TCR C $\beta$ genes. In order to determine the frequency of skewed $\mathrm{X}$ inactivation in peripheral blood leukocytes, PstI/HpalI digests of DNA from whole blood leukocytes were analyzed by M27 $\beta$ in 48 of the 86 individuals studied to determine constitutional heterozygosity. In 32 blood samples, ACR values were between 1.0 and 1.7, and thus considered to represent random $\mathrm{X}$ inactivation. 16 blood leukocyte samples (33\%) showed skewed $X$ inactivation (ACR 2.0-11.4).

3 of the 22 cancer patients studied were constitutionally heterozygous for the BamHI HPRT RFLP (Table I: cases 4, 10, 13), and four for the BglI PGK RFLP (Table I: cases 5, 8, $12,21)$.

Clonal analysis with M27 3 of tumors with otherwise established clonal composition (Table I and Figs. 3 and 4). In all 22 cancers, M27 $\beta$ analysis detected considerable skewing of $X$ inactivation, with ACR values of 2.7-> 100, hence well outside the range found in homologous normal tissue. These results were consistent with clonal tumors. The clonality of the neoplasms assessed by $M 27 \beta$ analysis was confirmed by X inactivation analysis with HPRT or PGK probes in informative cases (data not shown), and in all 22 cancers with DNA markers unrelated to the $\mathrm{X}$ inactivation strategy (Table I). 11

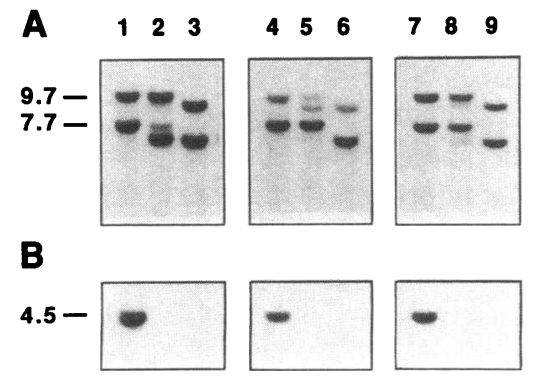

Figure 3. Comparative analysis of DNA from normal blood leukocytes (lanes $1-3$ ), tumor (lanes 4-6), and normal mucosa (lanes 7-9) in a case of colonic carcinoma (Table I: case 2). Southern blot autoradiography. Fragments indicated in $\mathrm{kb} .(A) \mathrm{M} 27 \beta$ probe. Enzymes: PstI

(lanes 1, 4, 7); PstI/HpaII (lanes 2, 5, 8), and PstI/MspI (lanes 3, 6, 9 ). (B) rehybridization with JH probe (lanes as in $A$ ). DNA from mucosa (lane 8 ) shows a random $\mathrm{X}$ inactivation pattern including partial methylation of the inactive $\mathrm{X}$ chromosome. The patterns in normal blood leukocytes and in the tumor are skewed. In lanes 4-6, the intensity of the 9.7-kb PstI band is reduced with respect to the 7.7-kb fragment, possibly due to slight partial degradation of tumor DNA.
A

$M 27 \beta$

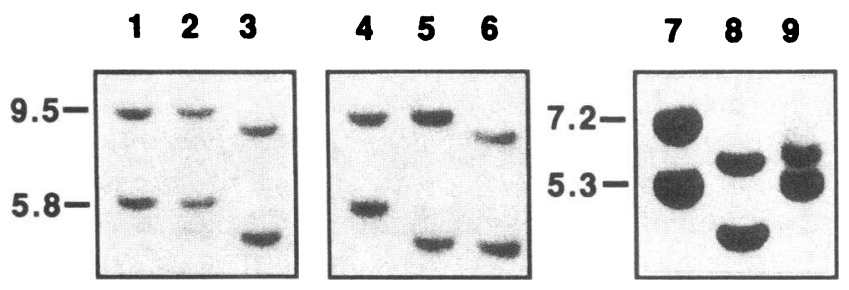

JH

123

456

$\begin{array}{lll}7 & 8 & 9\end{array}$
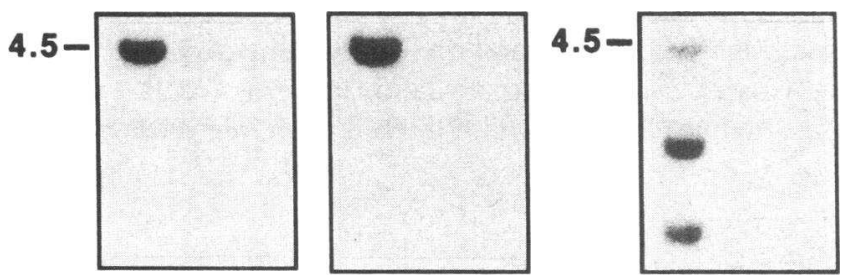

B
PYNZ22

12

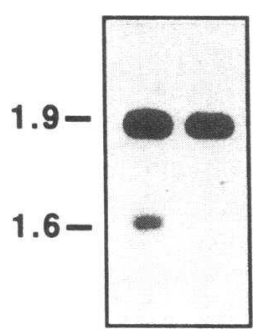

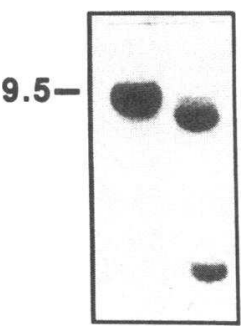

Figure 4. Clonal analysis of representative malignant neoplasms (Table I) with the M $27 \beta$ probe and other DNA markers. Autoradiographs from Southern blots. Fragments indicated in kb. (A, upper panel) M27 $\beta$ probe. Rectal cancer (case 1); (lanes 1-3) normal mucosa; (lanes 4-6) tumor; acute lymphoblastic leukemia (case 20); (lanes 7-9) DNA from leukemic blasts. Enzymes: PstI alone (lanes 1, 4, 7); PstI + HpaII (lanes 2, 5, 9); PstI + Msp I (lanes 3, 6, 8). X inactivation patterns in the tumor DNAs are markedly skewed, consistent with the presence of clonal neoplasms. ( $A$, lower panel) same filters rehybridized with $\mathrm{JH}$ probe. Lanes as in the upper panel. The 4.5-kb JHPstI fragment is digested away by HpalI/MspI. PstI digested DNA from the leukemia (lane 7) demonstrates two additional smaller bands due to clonal rearrangement of the $\lg$ heavy-chain gene. $(B)$ assessment of clonality with DNA markers other than M27 $\beta$. Rectal cancer (case 1); (lane 1) normal mucosa; (lane 2) tumor. SstI digest hybridized to pYNZ22 probe (17p). Acute lymphoblastic leukemia (case 20); (lane 3) normal control (unrelated individual), (lane 4) DNA from leukemic blasts. HindIII digest hybridized to JH probe. The rectal cancer shows clonal loss of heterozygosity at $17 p$, and the leukemia shows clonal JH gene rearrangement.

gastrointestinal and the two thyroid carcinomas showed clonal loss of heterozygosity at various loci, including $17 \mathrm{p}, 5 \mathrm{q}$, and $1 \mathrm{q}$. Three cancers were clonal based on DNA fingerprint analysis, 
and one showed a clonal somatic rearrangement at 1q. All lymphoid neoplasms showed clonally rearranged antigen receptor genes.

Rehybridization of all blots used for M27 $\beta$ analysis with the JH probe showed that HpalI cleaved the 4.5-kb JH-PstI fragment into smaller fragments not normally retained on gels prepared for M27 $\beta$ analysis (Fig. $3 B$ and $4 B$ ). This was taken to indicate absence of any enzyme inhibitors, such as impurities in the DNA, in the digest.

Clonal analysis of thyroid lesions (Table II and Fig. 5). 13 of 15 cases of rapidly growing benign thyroid nodules collected were constitutionally informative for M27 $\beta$ analysis. Normal thyroid tissue yielded polyclonal $\mathrm{X}$ inactivation patterns with ACR values in the range of 1.0-1.6 in nine cases. In case 13 , the ratio (1.9) was slightly outside the random range. Blood leukocyte DNA contained random $\mathrm{X}$ inactivation patterns in all cases but two (case 6: 2.5; case 10: 3.3). Nine nodules were found to be clonal on M27 $\beta$ analysis (ACRs 70-> 100), whereas three nodules and one case of Graves' goiter yielded polyclonal random $\mathrm{X}$ methylation patterns (ACR 1.0-1.7). One nodule (case 12 ) yielded a result in an intermediate range

Table II. Clonal Analysis of Benign Thyroid Nodules With the Probe M27 $\beta$

\begin{tabular}{|c|c|c|c|c|}
\hline \multirow[b]{2}{*}{ Case } & \multirow[b]{2}{*}{ Histological description of thyroid nodule } & \multicolumn{3}{|c|}{$\begin{array}{l}\text { M27 } \beta \text { probe:allelic } \\
\text { cleavage ratio }\end{array}$} \\
\hline & & WBC & $\begin{array}{l}\text { Normal } \\
\text { tissue* }\end{array}$ & Nodule \\
\hline 1 & $\begin{array}{l}\text { Monomorphic microfollicular } \\
\text { nodule }^{\ddagger}\end{array}$ & 1.3 & 1.2 & $>100$ \\
\hline 2 & Monomorphic solid nodule ${ }^{\ddagger}$ & 1.1 & 1.4 & 90 \\
\hline 3 & Monomorphic solid nodule ${ }^{\ddagger}$ & 1.2 & 1.4 & $>100$ \\
\hline 4 & $\begin{array}{l}\text { Macrofollicular nodule with } \\
\text { uniformly large cells }{ }^{\ddagger}\end{array}$ & 1.4 & NA & $>100$ \\
\hline 5 & $\begin{array}{l}\text { Solid nodule with multiple foci of } \\
\text { large cells }{ }^{\ddagger}\end{array}$ & 1.4 & NA & 70 \\
\hline 6 & $\begin{array}{l}\text { Nodule with proliferating macro- } \\
\text { and microfollicular foci }\end{array}$ & 2.5 & 1.6 & $>100$ \\
\hline 7 & $\begin{array}{l}\text { Highly polymorphic macro- and } \\
\text { microfollicular nodule } \\
\text { composed of uniformly large } \\
\text { cells }\end{array}$ & 1.2 & 1.6 & 100 \\
\hline 8 & $\begin{array}{l}\text { Nodule with multiple foci of } \\
\text { proliferating oxyphilic cells }{ }^{\ddagger}\end{array}$ & 1.2 & 1.0 & 85 \\
\hline 9 & $\begin{array}{l}\text { Nodule with proliferating macro- } \\
\text { and microfollicular foci }{ }^{\ddagger}\end{array}$ & 1.0 & 1.0 & 90 \\
\hline 10 & Graves' goiter & 3.3 & NA & 1.7 \\
\hline 11 & $\begin{array}{l}\text { Two separate nodules }(a+b) \\
\text { both containing proliferating } \\
\text { macro- and microfollicular foci }\end{array}$ & 1.25 & 1.1 & $\begin{array}{l}\text { (a) } 1.0 \\
\text { (b) } 1.2\end{array}$ \\
\hline 12 & $\begin{array}{l}\text { Nodule with proliferating foci of } \\
\text { irregularly shaped follicles } \\
\text { lined with uniform large cells }\end{array}$ & 1.6 & 1.0 & 2.0 \\
\hline 13 & $\begin{array}{l}\text { Tissue containing multiple very } \\
\text { small nodules with } \\
\text { proliferating polymorphic cells }\end{array}$ & 1.6 & 1.9 & 1.6 \\
\hline
\end{tabular}

* Normal tissue taken from macroscopically and histologically normal thyroid. $\quad$ * These lesions fulfill accepted criteria of thyroid "adenoma." WBC, white blood cells; NA, not analyzed/not available.

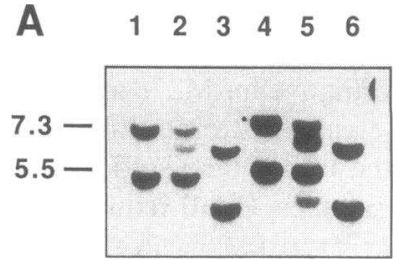

B $\quad \begin{array}{llllll}1 & 2 & 3 & 4 & 5 & 6\end{array}$

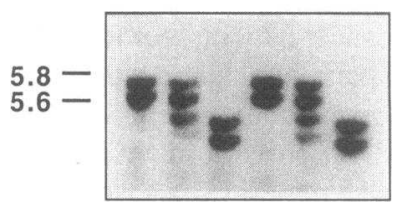

C

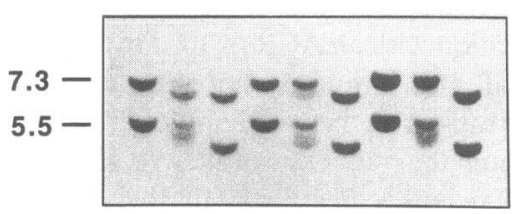
a multinodular goiter (panel $C$ ) show random $\mathrm{X}$ inactivation, and are therefore thought to represent polyclonal proliferations.

(ACR 2.0). The results were confirmed in four patients informative for either HPRT or PGK polymorphisms (data not shown; cases 4, 9; and cases 7, 13, respectively).

Other findings. None of the tumors analyzed with M27 $\beta$ showed any clonal loss of heterozygosity at DXS255, or any novel rearranged fragments representing somatic mutant alleles.

\section{Discussion}

Our study demonstrates that the $X$ chromosomal VNTR probe $\mathrm{M} 27 \beta$ is a very useful tool to study the clonal composition of a wide variety of tumors from virtually all female patients. M27 $\beta$ analysis of DNA from normal tissue homologous to the respective tumors, such as gastric or colon mucosa, was an adequate control, since it revealed polyclonal $\mathrm{X}$ inactivation patterns in all the cases studied. All cancer samples confirmed as being clonal by other DNA markers were shown to contain the predicted clonal X inactivation pattern on M27 $\beta$ analysis. Tumor clonality was also established by HPRT and PGK probes in those cases informative for these gene polymorphisms. It is important to note that, in marked contrast to M27 $\beta$ analysis, many of our cases were not informative for these latter probes.

We also used the M27 $\beta$ probe to study the clonal composition of rapidly growing, but clinically and histologically benign, thyroid nodules taken from multinodular goiters. Traditionally, such nodules are sometimes called "adenomas" based on ill-defined scintigraphic and histological criteria. In our series, nine of the nodules were clearly clonal, whereas four nodules, tissue from a case of Graves' goiter and normal thyroid tissue, were not, findings that are consistent with the literature $(2,10$, 33-35). Many, but not all, autonomously proliferating thyroid nodules ("adenomas") may, therefore, represent true clonal neoplasms. They are thought to originate from a single cell, or perhaps a small number of cells with a high constitutive growth 
potential passed on to their progeny. Such cells may be prone to undergoing somatic mutations and, hence, secondary clonal growth (36-39). In the thyroid, such putative somatic mutations are still largely unknown. However, Arnold et al. have recently detected a specific clonal aberration, translocation of the parathyroid hormone gene into the vicinity of a bcl-1linked oncogene, in another endocrine tumor, parathyroid adenoma $(24,40,41)$. The demonstration of the clonal nature of some thyroid nodules should similarly pave the path for further advances to be made in dissecting the molecular pathogenesis of autonomous nodular growth in the thyroid.

A relatively high number of DNA samples prepared from normal blood leukocytes showed "clonal" skewing of X inactivation, as similarly noted by other authors using the PGK (9) or the M27 $\beta$ probe $(15,19,20)$. Comparison of constitutional DNA from blood leukocytes and other tissues with M27 $\beta$ suggested that skewing of $\mathrm{X}$ chromosome inactivation may not be consistent from tissue to tissue (9), but may be tissue specific, notably present in blood leukocytes. The reason for this interesting finding is at present unknown. It may have important implications for the use of the M27 $\beta$ probe to detect carriers in $\mathrm{X}$-linked disorders, as recently investigated in the Wiskott-Aldrich syndrome $(22,42)$. From the point of view of tumor clonality assessment, it would seem that DNA from normal peripheral blood leukocytes is not an ideal control, and DNA from normal tissue homologous to the tumor type of interest should be examined. Thus, M27 $\beta$ may be of limited value for the clonal analysis of neoplasms and other cell populations derived from the hematopoietic system $(14,15,43)$, since it may be uncertain whether a skewed $X$ inactivation pattern seen with M27 $\beta$ points to the presence of a true clonal neoplasm, or is perhaps a reflection of normal variation of $\mathrm{X}$ inactivation in hematopoietic cells.

Two other cautionary remarks on the interpretation of clonal X inactivation studies seem warranted. M27 $\beta$ analysis indicates that tumors are homogeneous with respect to a particular skewed $\mathrm{X}$ inactivation pattern. While this finding is fully consistent with the notion of tumor clonality, it fails to provide any direct proof of a tumor's single cell origin $(8,9)$. Secondly, if a tumor arises from the simultaneous mitotic activity of a patch of several contiguous progenitor cells bearing the same $X$ inactivation pattern, a skewed pattern would erroneously be taken to indicate tumor monoclonality $(44,45)$. This problem cannot be satisfactorily addressed by $\mathrm{X}$ inactivation analysis using extracted DNA, since the study of single cells to identify the degree of mosaicism present in normal tissue is not possible.

In conclusion, our work has shown that the M27 $\beta$ probe is a very useful and efficient tool for the assessment of tumor clonality, most reliably in solid tumors. The main advantage of M27 $\beta$ over other polymophic markers is that with a combination of two restriction enzymes only, and this single highly informative probe, clonal $\mathrm{X}$ inactivation analysis is successful in tumors from almost all female patients.

\section{Acknowledgments}

We would like to thank Ms. M. Oestreicher and Ms. L. Theilkäs for excellent technical assistance. Dr. D. R. Higgs and Dr. J. S. Wainscoat for critically reviewing the manuscript. We are indebted to the following colleagues for providing DNA probes: Dr. S. Gendler (29), Professor A. J. Jeffreys (31), Dr. Y. Nakamura (28), Dr. T. H. Rabbitts (23, 32), Dr. G. Thomas (30), Dr. Y. Boyd and Dr. J. S. Wainscoat (16-19), and Prof. B. Vogelstein (9). We would like to thank the surgeons from the Department of Visceral Surgery, Inselspital (Professor L. H. Blumgart, Professor P. Gertsch, Dr. H. Baer, Dr. W. Schweizer and Dr. H. E. Wagner), and from the Department of Surgery, Tiefenauspital (Professor F. Nöthiger and Dr. St. Birrer), Berne, for their help in collecting tumor specimens.

This work was supported by grants from the Swiss National Foundation (31-28579.90 to Martin F. Fey, 31-9141.87 to Andreas Tobler, and 3.991-0.87 to Hugo Studer), and from the US/UK Fulbright Commission to Heather L. Hinds.

\section{References}

1. Knudson, A. G., Jr. 1985. Hereditary cancer, oncogenes, and antioncogenes. Cancer Res. 45:1437-1443.

2. Fialkow, P. J. 1976. Clonal origin of human tumors. Biochim. Biophys. Acta. 458:283-321.

3. Sklar, J., and L. M. Weiss. 1988. Applications of antigen receptor gene rearrangements to the diagnosis and characterization of lymphoid neoplasms. Annu. Rev. Med. 39:315-334.

4. Wainscoat, J. S., and M. F. Fey. 1990. Assessment of clonality in human tumors: a review. Cancer Res. 50:1355-1360.

5. Fey, M. F., R. A. Wells, J. S. Wainscoat, and S. L. Thein. 1988. Assessment of clonality in gastrointestinal cancer by DNA fingerprinting. J. Clin. Invest. 82:1532-1537.

6. Beutler, E., M. Yeh, and V. F. Fairbanks. 1962. Normal human female as a mosaic of X-chromosome activity: studies using the gene for G6PD deficiency as a marker. Proc. Natl. Acad. Sci. USA. 48:9-16.

7. Linder, D., and S. M. Gartler. 1965. Glucose-6-phosphate dehydrogenase mosaicism: utilization as a cell marker in the study of leiomyomas. Science (Wash. DC). 150:67-69.

8. Vogelstein, B., E. R. Fearon, S. R. Hamilton, and A. P. Feinberg. 1985. Use of restriction fragment length polymorphisms to determine the clonal origin of human tumors. Science (Wash. DC). 227:642-645.

9. Vogelstein, B., E. R. Fearon, S. R. Hamilton, A. C. Preisinger, H. F. Willard, A. M. Michelson, A. D. Riggs, and S. H. Orkin. 1987. Clonal analysis using recombinant DNA probes from the X-chromosome. Cancer Res. 47:4806-4813.

10. Namba, H., K. Matsuo, and J. A. Fagin. 1990. Clonal composition of benign and malignant human thyroid tumors. J. Clin. Invest. 86:120-125.

11. Fearon, E. R., S. R. Hamilton, and B. Vogelstein. 1987. Clonal analysis of human colorectal tumors. Science (Wash. DC). 238:193-197.

12. Bartram, C. R., W. D. Ludwig, W. Hiddemann, J. Lyons, M. Buschle, J. Ritter, J. Harbott, A. Fröhlich, and J. W. G. Janssen. 1989. Acute myeloid leukemia: analysis of ras gene mutations and clonality defined by polymorphic Xlinked loci. Leukemia (Basingstoke). 3:247-256.

13. Alexander, J. M., B. M. K. Biller, H. Bikkal, N. T. Zervas, A. Arnold, and A. Klibanski. 1990. Clinically non-functioning pituitary tumors are monoclonal in origin. J. Clin. Invest. 86:336-340.

14. Abrahamson, G., N. J. Fraser, Y. Boyd, I. Craig, and J. S. Wainscoat. 1990. A highly informative X-chromosome probe, M27 $\beta$, can be used for the determination of tumour clonality. Br. J. Haematol. 74:371-372.

15. Hodges, E., W. M. Howell, Y. Boyd, and J. L. Smith. 1991. Variable $\mathrm{X}$-chromosome DNA methylation patterns detected with probe M27 $\beta$ in a series of lymphoid and myeloid malignancies. Br. J. Haematol. 77:315-322.

16. Fraser, N. J., Y. Boyd, G. G. Brownlee, and I. W. Craig. 1987. Multi-allelic RFLP for M27 $\beta$, an anonymous single copy genomic clone at Xp11.3-Xcen (HGM9 provisional no. DXS255). Nucleic Acids Res. 15:9616.

17. Fraser, N. J., Y. Boyd, and I. Craig. 1989. Isolation and characterization of a human variable copy number tandem repeat at Xcen-p11.22 Genomics. 5:144148.

18. Boyd, Y., N. Fraser, M. Ross, T. Meitinger, and I. Craig. 1989. Methylation patterns around highly polymorphic loci on the human $\mathrm{X}$ chromosome; correlation with X-inactivation status. Genet. Res. 53:224.

19. Boyd, Y., and N. J. Fraser. 1990. Methylation patterns at the hypervariable X-chromosome locus DXS255 (M27 $\beta$ ): correlation with X-inactivation status. Genomics. 7:182-187.

20. Brown, R. M., N. J. Fraser, and G. K. Brown. 1990. Differential methylation of the hypervariable locus DXS255 on active and inactive $\mathrm{X}$ chromosomes correlates with the expression of a human X-linked gene. Genomics. 7:215-221.

21. Hendriks, R. W., and M. E. M. Kraakman, R. G. J. Mensink, and R. K. B. Schuurman. 1991. Differential methylation at the 5' and the $3^{\prime}$ CCGG sites flanking the X chromosomal hypervariable DXS255 locus. Hum. Genetics. 88:105111.

22. Hendriks, R. W., M. de Weers, R. G. J. Mensink, M. E. M. Kraakman, I. F. A. M. Mollee Versteegde, A. J. P. Veerman, L. A. Sandkuyi, and R. K. B. Schuurman. 1991. Diagnosis of Wiskott-Aldrich syndrome by analysis of the $\mathrm{X}$ chromosome inactivation patterns in maternal leucocyte populations using the hypervariable DXS255 locus. Clin. Exp. Immunol. 84:219-224. 
23. Flanagan, J. G., and T. H. Rabbitts. 1982. The sequence of a human immunoglobulin epsilon heavy chain constant region gene, and evidence of three non-allelic genes. EMBO (Eur. Mol. Biol. Organ.) J. 1:655-660.

24. Arnold, A., C. E. Staunton, H. G. Kim, R. D. Gaz, and H. M. Kronenberg. 1988. Monoclonality and abnormal parathyroid hormone genes in parathyroid adenomas. N. Engl. J. Med. 318:658-662.

25. Fey, M. F., C. Hesketh, J. S. Wainscoat, S. Gendler, and S. L. Thein. 1989. Clonal allele loss in gastrointestinal cancers. Br. J. Cancer. 59:750-754.

26. Fey, M. F., A. Tobler, B. Stadelmann, A. Hirt, L. Theilkäs, E. W. Khandjian, A. Ridolfi-Lüthy, B. Delaleu, R. Weil, and H. P. Wagner. 1990. Immunogenotyping with antigen receptor gene probes as a diagnostic tool in childhood acute lymphoblastic leukaemia. Eur. J. Haematol. 45:215-222.

27. Wong, Z., V. Wilson, I. Patel, S. Povey, and A. J. Jeffreys. 1987. Characterization of a panel of highly variable minisatellites cloned from human DNA. Ann. Hum. Genet. 51:269-288.

28. Nakamura, Y., L. Ballard, M. Leppert, P. O'Connell, G. M. Lathrop, J. M. Lalouel, and $\mathbf{R}$. White. 1988. Isolation and mapping of a polymorphic DNA sequence (pYNZ22) on chromosome 17p (D17S30). Nucleic Acids Res. 16:5707.

29. Swallow, D. M., S. Gendler, B. Griffiths, A. Kearney, S. Povey, D. Sheer, R. W. Palmer, and J. Taylor-Papadimitriou. 1987. The hypervariable locus PUM, which codes for the tumour associated epithelial mucins, is located on chromosome 1, within the region 1q21-24. Ann. Hum. Genet. 51:289-295.

30. Marlhens, F., O. Delattre, A. Bernard, S. Olschwang, B. Dutrillaux, and G. Thomas. 1987. RFLP identified by the anonymous DNA segment OL VII E10 at 18q21.3 (HGM no. D18S8). Nucleic Acids Res. 15:1348.

31. Jeffreys, A. J., V. Wilson, and S. L. Thein. 1985. Individual-specific "fingerprints" of human DNA. Nature (Lond.). 316:76-79.

32. Sims, J. E., A. Tunnacliffe, W. J. Smith, and T. H. Rabbitts. 1984. Complexity of human T-cell antigen receptor $\beta$-chain constant- and variable-region genes. Nature (Lond.). 312:541-545.

33. Thomas, G. A., D. Williams, and E. D. Williams. 1989. The clonal origin of thyroid nodules and adenomas. Am. J. Pathol. 134:141-147.

34. Hicks, D. G., V. A. LiVolsi, J. A. Neidich, J. M. Puck, and J. A. Kant. 1990. Clonal analysis of solitary follicular nodules in the thyroid. Am. J. Pathol. 137:553-562.
35. Namba, H., J. L. Ross, D. Goodman, and J. A. Fagin. 1991. Solitary polyclonal autonomous thyroid nodule: a rare cause of childhood hyperthyroidism. J. Clin. Endocrinol. Metab. 72:1108-1112.

36. Peter, H. J., H. Gerber, H. Studer, and S. Smeds. 1985. Pathogenesis of heterogeneity in human multinodular goitre. J. Clin. Invest. 76:1992-2002.

37. Peter, H. J., H. Gerber, H. Studer, D. V. Becker, and M. E. Peterson. 1987. Autonomy of growth and of iodine metabolism in hyperthyroid feline goiters transplanted onto nude mice. J. Clin. Invest. 80:491-498.

38. Studer, H., H. J. Peter, and H. Gerber. 1989. Natural heterogeneity of thyroid cells: the basis for understanding thyroid function and nodular goitre growth. Endocr. Rev. 10:125-135.

39. Studer, H., and H. Gerber. 1991. Pathogenesis of nontoxic diffuse and nodular goitre. In Werner's and Ingbar's The Thyroid. L. E. Braverman, and R. Utiger, editors. 6th edition, chapter 82. Lippincott \& Co., Philadelphia. pp. 11071113.

40. Arnold, A., H. G. Kim, R. D. Gaz, R. L. Eddy, Y. Fukushima, M. G. Byers, T. B. Shows, and H. M. Kronenberg. 1989. Molecular cloning and chromosomal mapping of DNA rearranged with the parathyroid hormone gene in a parathyroid adenoma. J. Clin. Invest. 83:2034-2040.

41. Motokura, T., T. Bloom, H. G. Kim, H. Jüppner, J. V. Ruderman, H. M. Kronenberg, and A. Arnold. 1991. A novel cyclin encoded by a bcl1-linked candidate oncogene. Nature (Lond.). 350:512-515.

42. Goodship, J., J. Carter, T. Espanol, Y. Boyd, S. Malcolm, and R. J. Levinsky. 1991. Carrier detection in Wiskott-Aldrich syndrome: combined use of M27 $\beta$ for X-inactivation studies and as a linked probe. Blood. 77:2677-2681.

43. Raghavachar, A., J. W. G. Janssen, H. Schrezenmeier, H. Heimpel, and C. R. Bartram. 1991. Clonal analysis of aplastic anemia using X-linked DNA polymorphisms. Int. J. Cell Cloning. 9:334 (Abstr.)

44. Thomas, G. A., D. Williams, and E. D. Williams. 1988. The demonstration of tissue clonality by X-linked enzyme histochemistry. J. Pathol. 155:101108.

45. Iannaccone, P. M., W. C. Weinberg, and L. Berkwits. 1987. A probabilistic model of mosaicism based on the histological analysis of chimaeric rat liver. Development (Camb.). 99:187-196. 